\title{
PROGRAM PENGUATAN SISTEM INOVASI DAERAH (SIDa) SEBAGAI EXIT STRATEGY PROGRAM NASIONAL PEMBERDAYAAN MASYARAKAT (PNPM)
}

\section{Regional Innovation System Strengthening Program (SIDa) As An Exit Strategy National Community Development Program (PNPM)}

\author{
Teguh Narutomo \\ Pusat Penelitian dan Pengembangan Kesatuan Bangsa, Politik dan Otonomi Daerah \\ Badan Penelitian dan Pengembangan (BPP) Kementerian Dalam Negeri \\ J1. Kramat Raya No. 132 - Senen, Jakarta, Telp./Faks: +62 21314 0454; \\ E-mail: narutomo_litbang@yahoo.com, Tlp.0818 103923 \\ Diterima: 16 Maret 2014, direvisi: 23 April 2014, disetujui: 12 Mei 2014
}

\begin{abstract}
Abstrak
Penelitian ini bertujuan melakukan evaluasi terhadap program PNPM dan menentukan exit strategy program dengan pengembangannya yaitu melalui Program Penguatan SIDa. Metodologi penelitian yang digunakan adalah metode kualitatif dengan pendekatan penelitian ini melalui sebagai desain riset evaluasi yang dibangun berdasarkan model evaluasi CIPP (Context-Input-Process-Product). Kegagalan teori dan model pembangunan yang terlalu mengagungkan pertumbuhan, membuat banyak kalangan beralih kepada pembangunan yang memusatkan kepada rakyat, yang didalamnya mensyaratkan optimasi sumberdaya lokal, partisipasi, dan pemberdayaan masyarakat. Sejak saat itulah, "pemberdayaan" yang dikenalkan di Indonesia telah membius banyak kalangan dan dijadikan tumpuan harapan banyak pihak. Pada tahun 2007 dimulai Program Nasional Pemberdayaan Masyarakat (PNPM) yang melanjutkan Program Pengembangan Kecamatan (PPK). Tahun 2014 PNPM yang merupakan bagian dari program Kabinet Indonesia Bersatu Jilid 2 sudah akan berakhir. Untuk itu perlu dicarikan exit strategy program yang dapat menjaga keberlanjutan dan kesinambungan PNPM. Program Penguatan Sistem Inovasi Daerah (SIDa) merupakan program dari keseluruhan proses dalam satu sistem untuk menumbuhkembangkan inovasi yang dilakukan antar institusi pemerintah, pemerintahan daerah, lembaga kelitbangan, lembaga pendidikan, lembaga penunjang inovasi, dunia usaha, dan masyarakat di daerah yang telah dicanangkan sejak tahun 2012. Program SIDa merupakan program pemberdayaan juga, baik kepada masyarakat dan bahkan pemberdayaan kepada seluruh elemen seperti akademisi, swasta, pemerintah dan masyarakat.

Kata Kunci: exit strategy, Program Nasional Pemberdayaan Masyarakat (PNPM), Sistem Inovasi Daerah (SIDa)
\end{abstract}

\begin{abstract}
The aim of this study was to evaluate the PNPM program and follow the program with SIDA Strengthening Program. The research method used is a qualitative method approach of this research through the evaluation research design that builds on the CIPP evaluation model (Context-InputProcess-Product). Since the failure of theories and models of development are too glorifies growth, makes many people turn to focus on people development, which includes requiring optimization of local resources, participation, and empowerment. Since then, "empowerment" which was introduced in Indonesia has been anesthetized and made many hopes among many parties. In 2007 started the National Program for Community Empowerment (PNPM) which continue Kecamatan Development Program (KDP). PNPM 2014 which is part of the United Indonesia Cabinet Volume 2 is going to end. For that we need to look for an exit strategy program that can maintain sustainability of PNPM. Regional Innovation Systems Strengthening Program (SIDA) is a program of the whole process in one system to foster innovation made between government institutions, local governments, kelitbangan institutions, educational institutions, innovation support institutions, businesses, and communities in areas that have been implemented since the 2012 SIDA program is an empowerment program as well, both to the public and even empowering to all elements such as academia, private industry, government and society.

Keywords: exit strategy, the National Program for Community Empowerment (PNPM), Regional Innovation Systems Program (SIDa), the CIPP evaluation model (Context-Input-Process-Product.
\end{abstract}

\section{PENDAHULUAN}

Pemberdayaan masyarakat, dewasa ini telah menjelma sebagai program nasional melalui PNPM (Program Nasional Pemberdayaan Masyarakat), sehingga tidak satupun SKPD (Satuan Kerja Pemerintah Daerah) yang tidak memiliki program/kegiatan pemberdayaan masyarakat. Bahkan, di seluruh provinsi, dan kabupaten/kota, 
perlu dibentuk instansi khusus yang bernama Badan/Kantor Pemberdayaan Masyarakat.

Demikian juga di dalam struktur pemerintah desa/kelurahan, juga dibentuk Lembaga Pemberdayaan Masyarakat Desa/Kelurahan (LPMD/LPMK). Tidak cukup di situ, di kalangan dunia-usaha, baik Badan Usaha Milik Negara (BUMN)/Swasta, juga ada kewajiban melakukan pemberdayaan masyarakat melalui progran tanggungjawab sosial dan lingkungan dalam bentuk: Program Kemitraan dan Bina Lingkungan (PK-BL) di BUMN, maupun CSR (Corporate Social Responsibility) di kalangan Swasta.

Tetapi, kenyataan menunjukkan bahwa praktek pelaksanaan pemberdayaan masyarakat seringkali jauh meleset dari konsepnya. Pemberdayaan menjadi lebih "memperdayai", upaya pengembangan kemandirian masyarakat justru lebih cenderung melestarikan ketergantungan masyarakat kepada beragam bentuk bantuan, pinjaman lunak, modal bergulir, dll. Lebih ironisnya, program/kegiatan pemberdayaan masyarakat tidak sedikit yang dijadikan ladang manipulasi dan korupsi.

Program Nasional Pemberdayaan Masyarakat (PNPM) telah dilaksanakan selama 6 (enam) tahun, yang dicanangkan oleh pemerintahan Susilo Bambang Yudoyono (SBY) sejak tahun 2007. Pada tahun 2014, pemerintahan SBY akan berkahir, hal ini akan membuat semua program periode kabinet SBY, akan dievaluasi dan kemudian diputuskan berlanjut atau dihentikan. Untuk itu agar PNPM dapat memberi manfaat secara berkesinambungan bagi masyarakat Indonesia, maka diperlukan strategy langkah yang tepat sebagai langkah tindak lanjut dari program tersebut.

Sejarah menunjukkan bahwa keberhasilan pembangunan ekonomi tidak lagi dapat dicapai semata-mata dengan bertumpu pada sumber daya alam tanpa upaya yang lebih baik terhadap nilai tambah produknya. Perkembangan perekonomian internasional yang berkecenderungan didominasi oleh aktivitas dan produk yang semakin sarat dengan pengetahuan/teknologi yang intensif (knowledge/technology intensive) semakin menyisihkan posisi negara seperti Indonesia yang secara "konvensional" masih bergantung pada aktivitas dan produk bernilai tambah rendah.

Proses perbaikan posisi Indonesia di lingkungan internasional akan sangat terkait dengan upaya-upaya yang sungguh-sungguh dan lebih terarah. Dengan cara membangun fondasi dan pilarpilar serta menumbuhkembangkan aktivitas/proses produktif. dan memperkuat dinamika interaksi serta keterkaitannya sebagai determinan bagi pembentukan keunggulan daya saing Indonesia, baik pada tataran daerah maupun nasional. Kecenderungan pergeseran kepada konteks "daerah" (lokalitas) sebenarnya bukanlah sekedar perkembangan sentimentalisme kedaerahan. Hal ini memang dapat dianggap sebagai kecenderungan perkembangan paradigma tentang daya saing yang semakin diyakini sangat kontekstual dengan dinamika perubahan yang dihadapi di era sekarang. Sebagaimana juga diungkap oleh berbagai pakar dengan cara yang beragam namun menyampaikan inti pesan serupa, bahwa daya saing global semakin ditentukan oleh faktor-faktor lokalitas, dan agenda peningkatan daya saing perlu beriringan dengan upaya penguatan kohesi sosial masyarakat yang semakin maju.

Dalam kaitan ini, inovasi dipandang sebagai faktor yang sangat mempengaruhi, jika tidak "menentukan (determinan)." Inovasi memungkinkan pembaruan yang membawa kepada perbaikan dalam kehidupan masyarakat. Kesadaran tentang ini, walaupun telah lama berkembang, perlu terus diperbarui. Perubahan yang terus terjadi seringkali memerlukan cara pikir, sikap dan tindakan yang lebih baik dan juga seringkali "berbeda' dari sebelumnya. Demikian halnya dengan inovasi. Perubahan itu sendiri, yang akan terus terjadi, memerlukan perbaikan dalam pemahaman dan upaya-upaya mendorong berkembangnya inovasi untuk mengatasi/menghadapi dinamika tantangan perubahan tersebut. Cara pandang atau pendekatan sistem kini berkembang sebagai suatu alat untuk memperbaiki kebijakan inovasi pada berbagai tataran.

Pendekatan sistem yang diberlakukan adalah menyertakan semua pihak untuk bersama-sama bekerja dan bertangungjawab, baik dari pihak pemerintah, swasta maupun masyarakat. Pendekatan sistem inovasi yang dilakukan di setiap daerah, diharapkan menjadi langkah yang paling bijaksana untuk meningkatkan daya saing bangsa Indonesia. Daya saing bangsa dapat diwujudkan dengan cara lebih memberdayakan masyarakat secara lebih terarah, fokus, dan bersinergi dengan semua pihak terkait, sehingga menghasilkan produk yang memiliki daya saing yang tinggi. Maka melalui pendekatan Sistem Inovasi Daerah (SIDa), dianggap dapat menjadi exit strategy dari Program Nasional Pemberdayaan Masyarakat (PNPM) yang telah menanamkan dasar pemberdayaan masyarakat di seluruh Indonesia.

Dari latarbelakang tersebut diatas, maka ditetapkan tujuan penelitian ini yaitu melakukan evaluasi terhadap program PNPM dan exit strategy program tersebut dengan Program Penguatan SIDa. Dimana rumusan masalah yang dibangun adalah "sejauhmana pelaksanaan Program Nasional Pemberdayaan Masyarakat; dan bagaimana exit strategy Program Nasional Pemberdayaan Masyarakat; sejauhmana kesiapan Program Penguatan Sistem Inovasi Daerah sebagai exit startegy PNPM". 


\section{METODE PENELITIAN}

Metode penelitian yang digunakan dalam penelitian ini adalah metode kualitatif, dimana penelitiannya pada kondisi objek yang alami dan peneliti adalah instrumen kunci. Teknik pengumpulan data dilakukan secara triangulasi (gabungan) sedangkan data yang dihasilkan bersifat deskriptif dan analisis datanya dilakukan secara induktif. Hasil penelitian kualitatif lebih menekankan makna daripada generalisasi (Sugiyono, 2008).

Pendekatan penelitian ini melalui sebagai desain riset evaluasi yang dibangun berdasarkan model evaluasi CIPP (Context-Input-ProcessProduct) kemudian dikembangkan (Stuflebeam, dkk), dengan menerapkan komponen-komponen dalam sistem.

PNPM Mandiri diukur berdasarkan perbandingan atau kesesuaian antara intensitas objektif (kondisi aktual) dari komponen context, input, process, and product program tersebut dengan standar-standar objektif (kondisi ideal) yang telah ditetapkan (secara kuantitas dan kualitas), dan kemudian dilakukan penilaian efektivitas/ performansi pada setiap tahapan/komponen evaluasi program. Kategori penilaiannya, hanya 3 (tiga) pilihan, yaitu high, moderate, dan low (Issac dan Michael, 2001). Setelah itu ditentukan langkah pengakhiran programnya (exit strategy) dimana strategi pengakhiran programnya adalah phasedown (fase penurunan), phaseover (fase pengalihan), dan phaseout (fase penghentian) (Rogers and Macias 2004: 4), dan kemudian diajukan saran-saran.
Berdasarkan uraian di atas, maka kerangka berpikir sebagai desain riset exit strategy PNPM Mandiri ini dapat digambarkan seperti di bawah ini:

\section{Kerangka Teoritis}

1. Program Nasional Pemberdayaan Masyarakat (PNPM)

Selama ini telah banyak program-program pembangunan dari pemerintah yang bertujuan untuk mengurangi masalah kemiskinan. Seperti Inpres Desa Tertinggal (IDT), pemberian Bantuan Langsung Tunai (BLT), Beras untuk Masyarakat Miskin (Raskin), Kompensasi Bahan Bakar Minyak, Program Pengembangan Kecamatan (PPK), Program Penanggulangan Kemiskinan Perkotaan (P2KP), dan berbagai program lainnya. Namun, dari program yang telah dilaksanakan oleh pemerintah tersebut masih terdapat kekurangan-kekurangan dalam pelaksanaannya dan belum dapat mampu mengurangi tingkat kemiskinan di Indonesia.

Menurut Prihartini, pada dasarnya ada dua faktor penting yang dapat menyebabkan kegagalan dalam program penanggulangan kemiskinan di Indonesia. Pertama, program-program penanggulangan kemiskinan selama ini cenderung berfokus pada upaya penyaluran bantuan sosial untuk orang miskin. Hal tersebut berupa beras untuk rakyat miskin dan program Jaring Pengaman Sosial (JPS) untuk orang miskin. Upaya seperti ini akan sulit untuk menyelesaikan persoalan kemiskinan yang ada karena sifat bantuan tidaklah untuk pemberdayaan, bahkan dapat menimbulkan ketergantungan bahkan dapat memperburuk

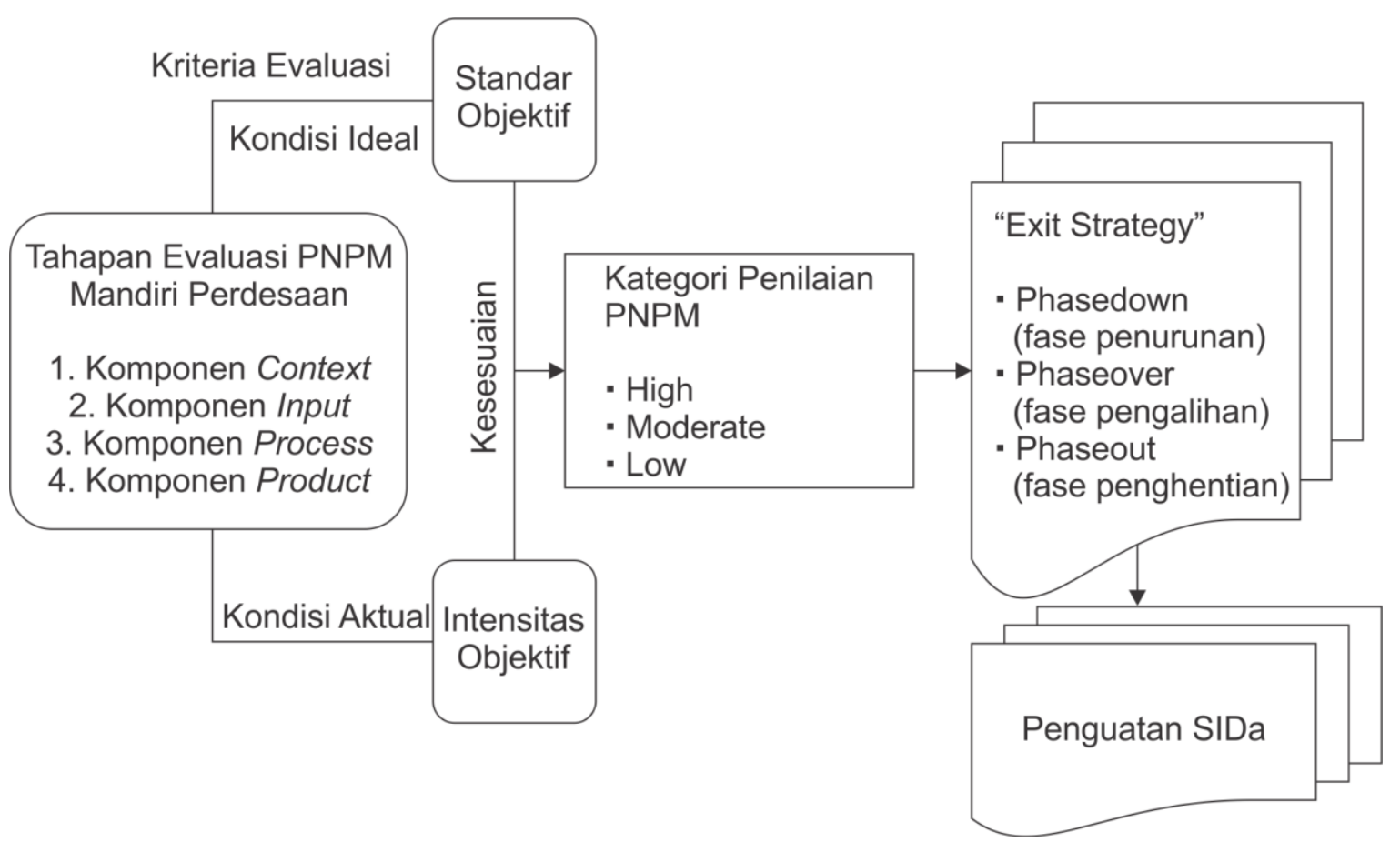

Gambar 1. Desain Riset Exit Strategy PNPM Mandiri 
masyarakat miskin dan dalam penyalurannya pun dapat menimbulkan korupsi. Faktor kedua yang dapat mengakibatkan gagalnya program penanggulangan kemiskinan adalah kurangnya pemahaman berbagai pihak tentang penyebab kemiskinan itu sendiri, sehingga program-program pembangunan yang ada tidak didasarkan pada isu-isu kemiskinan. Karena sebenarnya penyebab kemiskinan itu berbeda-beda pada masing-masing daerah. (www.resitory.gunadarma.ac.id).

Salah satu pendekatan yang dapat dilakukan dalam meningkatkan kualitas kehidupan dan mengangkat harkat martabat keluarga miskin adalah pemberdayaan masyarakat. Konsep ini menjadi sangat penting karena memberikan perspektif positif terhadap masyarakat miskin. Orang miskin tidak dipandang sebagai orang yang serba kekurangan (misalnya kurang makan, kurang pendapatan, kurang sehat dan kurang dinamis) dan obyek pasif penerima pelayanan belaka. Melainkan sebagai orang yang memiliki beragam kemampuan yang dapat dimobilisasi untuk perbaikan hidupnya.

Pada tahun 2000, Indonesia termasuk salah satu dari 189 negara di dunia yang menandatangani Deklarasi Perserikatan Bangsa-Bangsa tentang upaya, sasaran dan target-target pembangunan manusia dan pengentasan kemiskinan yang terkenal dengan nama Millennium Development Goals (MDGs). Deklarasi itu pada intinya merupakan komitmen bersama untuk menurunkan tingkat kemiskinan global dan kelaparan. Dengan demikian, pemerintah Indonesia telah membuat komitmen nasional untuk memberantas kemiskinan dalam rangka pelaksanaan pembangunan berkelanjutan (sustainable development). Dimana pemerintah dan semua perangkatnya dalam semua level, baik pemerintah pusat, provinsi, kabupaten/kota bersamasama dengan berbagai unsur masyarakat memikul tanggung jawab utama untuk mewujudkan pembangunan berkelanjutan dan sekaligus memberantas kemiskinan yang terjadi di Indonesia paling lambat tahun 2015 .

Oleh sebab itu, upaya pemerintah mengurangi kemiskinan terus menerus dilakukan, dan kini yang sedang dikembangkan adalah Program Nasional Pemberdayaan Masyarakat untuk masyarakat miskin perkotaan dan juga perdesaan yang telah dilaksanakan hampir pada seluruh wilayah Indonesia yaitu Program Nasional pemberdayaan Masyarakat Mandiri (PNPM-Mandiri).

Mulai tahun 2007 Pemerintah Indonesia mencanangkan Program Nasional Pemberdayaan Masyarakat (PNPM) Mandiri yang terdiri dari PNPM Mandiri Perdesaan, PNPM Mandiri Perkotaan, serta PNPM Mandiri Wilayah Khusus dan Desa Tertinggal. Program Nasional Pemberdayaan Masyarakat Mandiri Perdesaan (PNPM Mandiri Perdesaan) merupakan salah satu program pemberdayaan masyarakat yang digunakan dalam upaya mempercepat penanggulangan kemiskinan dan perluasan kesempatan kerja di wilayah perdesaan. PNPM Mandiri Perdesaan mengadopsi sepenuhnya mekanisme dan prosedur Program Pengembangan Kecamatan (PPK) yang selama ini dianggap berhasil di laksanakan. Keberhasilan PPK tersebut adalah penyediaan lapangan kerja dan pendapatan bagi kelompok rakyat miskin, efisiensi, dan efektivitas kegiatan dan keberhasilannya menumbuhkan kolektivitas dan partisipasi masyarakat

Pemberdayaan merupakan suatu konsep untuk memberikan tanggungjawab yang lebih besar kepada orang-orang tentang bagaimana melakukan pekerjaan. Pemberdayaan akan berhasil jika dilakukan oleh pengusaha, pemimpin dan kelompok yang dilakukan secara terstruktur dengan membangun budaya kerja yang baik. Konsep pemberdayaan terkait dengan pengertian pembangunan masyarakat dan pembangunan yang bertumpu pada masyarakat.

Program-program pemberdayaan sumberdaya manusia telah dilakukan pemerintah. Hal ini sejalan dengan tujuan pembangunan Indonesia yaitu membangun manusia Indonesia seutuhnya, maka pembangunan harus merupakan perubahan sosial yang tidak hanya terjadi pada taraf kehidupan masyarakat belaka tetapi juga pada peranan unsurunsur didalamnya.

Pemberdayaan menempatkan manusia sebagai subyek pembangunan. Pemberdayaan masyarakat dalam penanggulangan kemiskinan menjadi komitmen bersama antara pemerintah pusat dengan pemerintah daerah. Kemiskinan merupakan masalah pembangunan kesejahteraan sosial yang berkaitan dengan berbagai bidang pembangunan lainnya yang ditandai oleh pengangguran, keterbelakangan, dan ketidakberdayaan. Oleh karena itu, kemiskinan terutama yang diderita oleh kaum miskin merupakan masalah pokok nasional yang penanggulanggannya tidak dapat ditunda lagi dan harus menjadi prioritas utama dalam pelaksanaan pembangunan kesejahteraan sosial.

Pendekatan pemberdayaan masyarakat dimaksudkan untuk memperbaiki stabilitas sosial, membuka lapangan kerja, memperbaiki tata pemerintahan daerah dan menciptakan aset untuk kelompok miskin. Program-program penanggulangan kemiskinan dan penciptaan lapangan kerja yang berbasis pemberdayaan masyarakat dicirikan dengan: a) menggunakan pendekatan partisipasi masyarakat; b) melakukan penguatan kapasitas kelembagaan masyarakat; dan c) kegiatan program dilaksanakan secara swakelola oleh masyarakat.

\section{Sistem Inovasi Daerah (SIDa)}

Inovasi adalah kegiatan penelitian, pengembangan, dan/atau perekayasaan yang bertujuan mengembangkan penerapan praktis nilai dan konteks ilmu pengetahuan yang baru, atau cara 


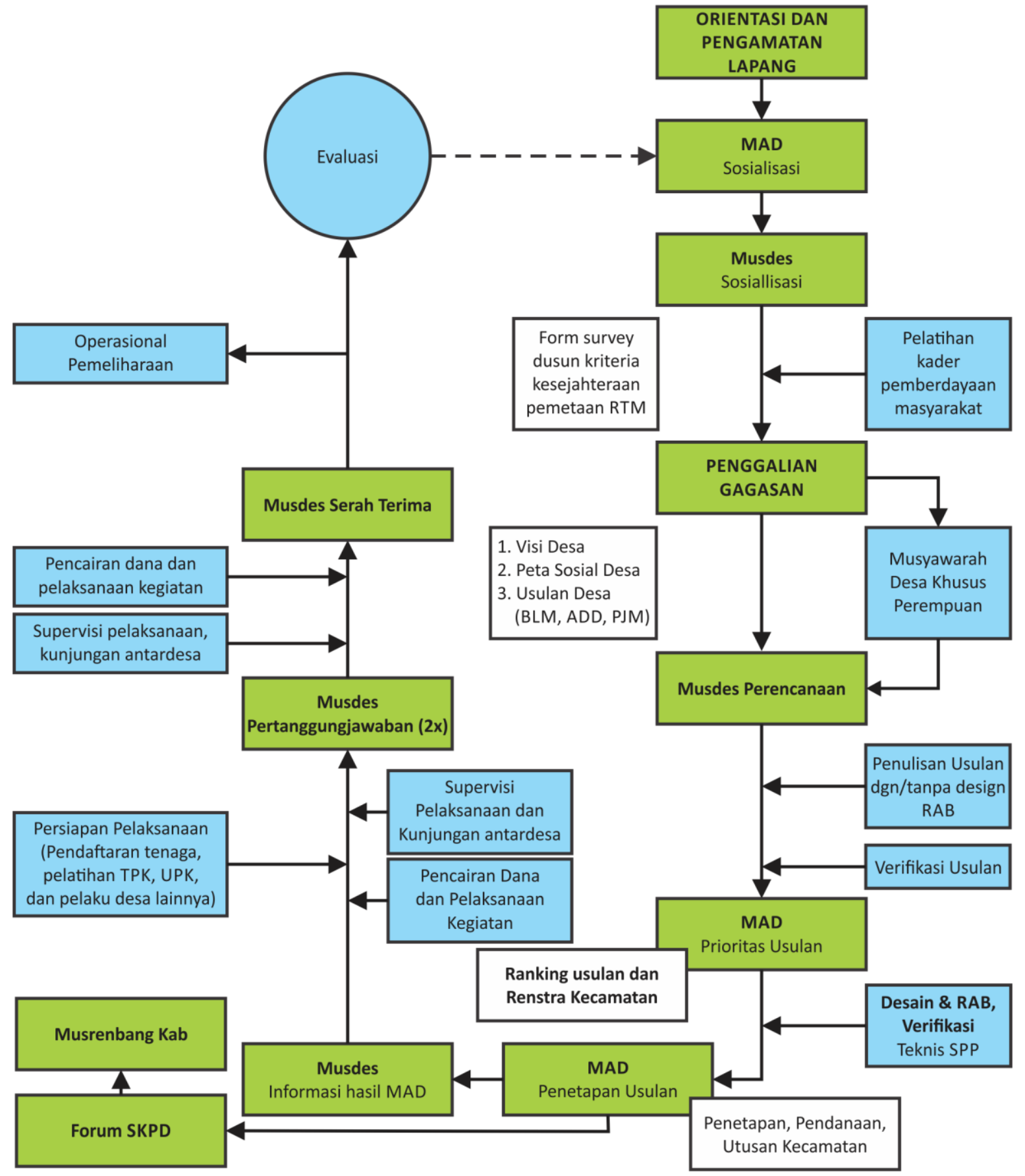

Gambar 2. Alur tahapan PNPM Mandiri

baru untuk menerapkan ilmu pengetahuan dan teknologi yang telah ada ke dalam produk atau proses produksi (UU No.18 tahun 2002 tentang Sistem Nasional Penelitian, Pengembangan, dan Penerapan Ilmu Pengetahuan dan Teknologi).

Sistem Inovasi merupakan sistem yang menghimpun institusi-institusi berbeda yang berkontribusi secara bersama/individu dalam pengembangan dan difusi teknologi dan menyediakan framework (kerangka kerja) dimana pemerintah pusat/daerah membentuk dan mengimplementasikan kebijakan untuk mempengaruhi proses inovasi. Sistem Inovasi merupakan himpunan lembaga-lembaga pasar dan non pasar di suatu negara yang mempengaruhi arah dan kecepatan inovasi dan difusi teknologi (OECD).

Pentingnya sistem inovasi bagi bangsa Indonesia agar menjadi negara maju yang berbasiskan pada kemampuannya dalam pengembangan, penguasaan dan pemanfaatan 


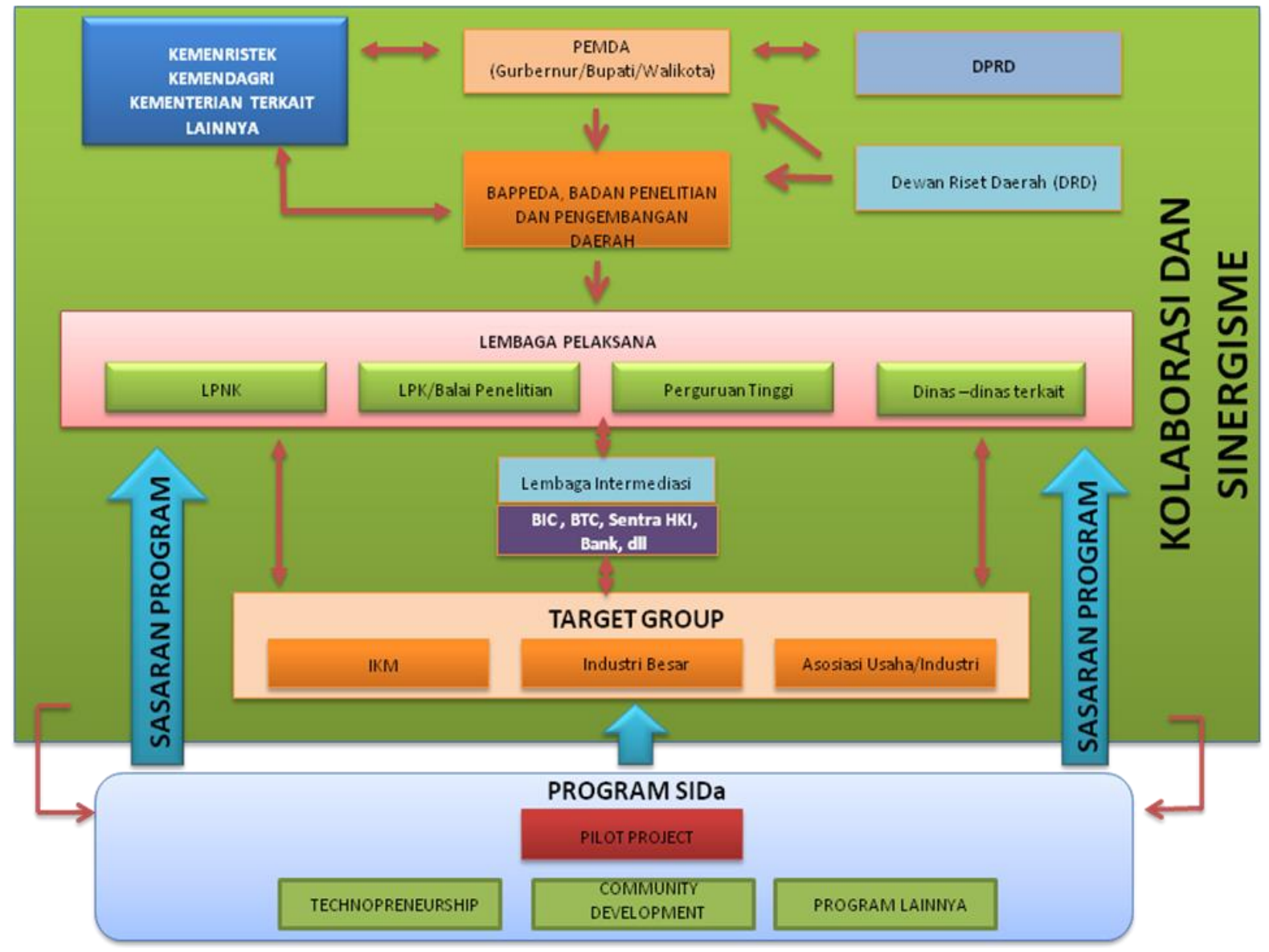

Gambar 3. Organisasi SIDa

teknologi, telah ditegaskan kembali melalui Masterplan Percepatan dan Perluasan Pembangunan Ekonomi Indonesia (MP3EI) 2011 - 2025. Salah satu strategi utama dalam MP3EI adalah Penguatan Kemampuan SDM dan Iptek Nasional dengan salah satu program utama adalah memperkuat operasionalisasi Sistem Inovasi Nasional.

Pengembangan Sistem Inovasi Nasional harus sejalan dengan pelaksanaan otonomi daerah. Penyebaran Iptek ke seluruh wilayah akan terjadi secara efektif melalui pemberdayaan dan pembentukan serta penataan sumberdaya Iptek daerah, baik yang menyangkut kelembagaan, program, sumberdaya manusia, keuangan, maupun sarana dan prasarananya (SIDa).

Perkembangan Sistem Inovasi Nasional harus dapat memfasilitasi dan menstimulasi pemerintah daerah agar mampu menumbuhkan sumber daya iptek secara efektif dan efisien, serta mengembangkan sinerginya dengan faktor pasar, perkembangan sektor produksi, serta perkembangan iklim usaha yang kompetitif di daerahnya masingmasing, sehingga kemampuannya untuk melaksanakan proses pertambahan nilai dapat terus ditingkatkan secara berkelanjutan, sesuai dengan potensi dan karakteristiknya masing-masing
Keberadaan dari MP3EI tersebut, seolah menjadi darah segar bagi berbagai pihak untuk bahu membahu dalam penguatan sistem inovasi baik pada level nasional maupun level daerah yang pada gilirannya dapat mendorong tumbuh dan berkembangnya inovasi yang berbasis pada keunggulan komparatif di 6 koridor ekonomi. Hal ini didasarkan pada inisiatif pelaksanaan inovasi dalam MP3EI antara lain Pengembangan Klaster Inovasi untuk mendukung 6 (enam) Koridor Ekonomi dan Pembentukan Klaster Inovasi Daerah untuk Pemerataan Pertumbuhan.

Pembentukan klaster inovasi daerah tersebut, tentunya memerlukan interaksi dan sinergi yang intensif dan terus menerus antar elemen dalam sistem inovasi di daerah baik dari unsur akademisi, pemerintah, industri maupun masyarakat. Selain dukungan dari para peneliti, pelaku industri dan masyarakat, peran pemerintah daerah untuk mewujudkan lingkungan/ekosistem yang kondusif melalui kebijakan dan regulasi yang tepat dan kosisten merupakan salah satu kunci keberhasilan pembentukan klaster inovasi daerah. Untuk itu, prakarsa dan keinginan membangun sinergi tersebut harus tumbuh dari pemerintah daerah yang didukung oleh stakeholder lainnya, sehingga keinginan 


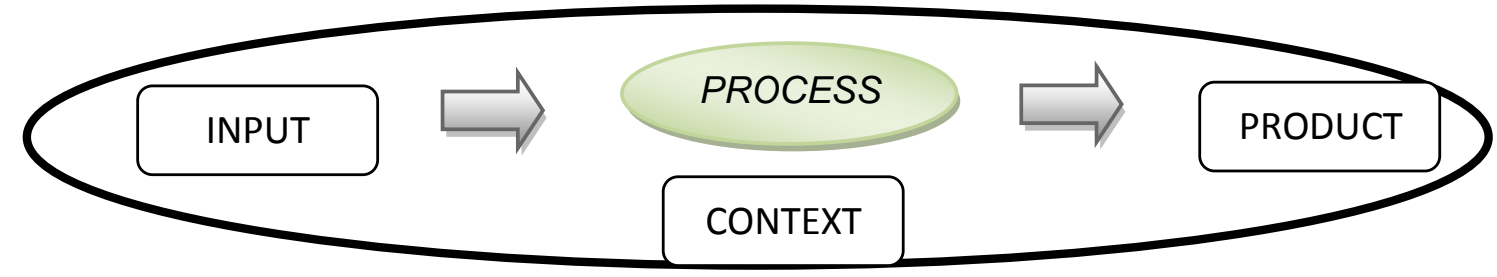

Sumber : World Agroforestry Center 2003 (2007).

Gambar 4. Model Evaluasi CIPP

pembentukan klaster inovasi daerah dalam kerangka sistem inovasi daerah dapat segera terwujud.

Oleh karena itu, Sistem Inovasi Daerah dan di tingkat nasional Sistem Inovasi Nasional harus diupayakan secara serasi dan saling menunjang, sehingga perkembangan Sistem Inovasi Daerah merupakan bagian terpadu dan tidak dapat dipisahkan dari perkembangan Sistem Inovasi Nasional. Karena itu program penguatan sistem inovasi daerah (SIDa) merupakan program yang dilakukan dengan cara penguatan terhadap programprogram inovasi yang telah dilakukan.

\section{Strategi Pengakhiran (exit strategy) Program}

Menurut Rogers and Macias (2004: 8), strategi pengakhiran (exit strategy) suatu program adalah rencana khusus yang menggambarkan bagaimana suatu program akan ditarik dari suatu wilayah sementara pencapaian tujuan pembangunan dapat dipastikan tidak akan terganggu dan perkembangan tujuan lebih lanjut akan dicapai. Tujuan strategi pengakhiran program adalah untuk memastikan keberlanjutan dampak dan kegiatan setelah program berakhir. Oleh karena itu, strategi pengakhiran program merupakan bagian penting dari suatu program.

Ada tiga jenis strategi pengakhiran suatu program, yaitu phasedown (fase penurunan), phaseover (fase pengalihan), dan phaseout (fase penghentian) (Rogers and Macias 2004: 4). Phasedown adalah pengurangan aktivitas program secara bertahap dalam rangka persiapan phaseover atau phaseout. Phaseover adalah tahap penyerahan tanggung jawab kegiatan/pengelolaan program kepada lembaga atau individu yang berada di wilayah pelaksanaan program. Sementara itu, phaseout adalah kegiatan menarik atau menghentikan sumber daya sebuah program tanpa menyerahkan tanggung jawab kepada lembaga atau kelompok lain.

Pemilihan strategi pengakhiran program yang akan diterapkan tergantung pada tujuan dan karakteristik suatu program. Jika tujuan dan perubahan yang ingin dicapai oleh sebuah program bersifat permanen dan berkelanjutan (selfsustaining), serta keberlanjutan dampaknya tidak memerlukan program atau kegiatan lainnya, maka pendekatan strategi pengakhiran yang dapat diterapkan adalah pendekatan phaseout. Contohnya adalah program yang menghasilkan perubahan perilaku dan pembangunan infrastruktur. Sementara strategi lainnya, yaitu phasedown dan phaseover, mensyaratkan adanya keterlibatan komponen masyarakat, individu, atau pemerintah dalam menjamin keberlangsungan dampak dari sebuah program.

Mengapa suatu program perlu diakhiri? Paling tidak ada tiga alasan untuk menghentikan sebuah program. Pertama, ada batasan waktu pelaksanaan program yang terkait dengan siklus pendanaan (funding cycle); kedua, target atau dampak pada tingkat tertentu telah tercapai; dan ketiga, benchmark (tolak ukur) yang mengindikasikan kemajuan dalam menghadapi phaseout atau phaseover telah tercapai.

\section{The CIPP Evaluation Model}

Model evaluasi program dan pengkategoriannya juga cukup beragam, misalnya, didasarkan pada siapa penemunya, pendekatan, dan konsep evaluasi itu sendiri. Salah satu model evaluasi program adalah The CIPP Evaluation Model. Oleh Isaac dan Michael, model itu digolongkan sebagai evaluasi yang berorientasi pada keputusan (decision oriented evaluation) (Isaac dan Michael, 2001), atau Decision Making Model menurut klasifikasi House (Madaus, Scriven, dan Stufflebeam, 2000), atau The CIPP Evaluation Model yang dikembangkan oleh Daniel L. Stufflebeam menurut pembagian evaluasi dari Kaufman dan Thomas (2002).

Penentuan mana yang cocok (sesuai atau pas) digunakan di antara model-model evaluasi program yang ada tentunya harus sesuai dengan kebutuhan, situasi, dan kondisi setempat, atau didasarkan pada keeratan kaitan evaluasi program dengan jenis program yang akan dievaluasi.

Salah satu jenis program yang dinyatakan oleh Lynton dan Pareek (2002) adalah program pengembangan atau pemberdayaan orang. Fokus dari program ini antara lain peningkatan keberdayaan orang yang lebih baik dari keadaan sebelumnya dan kondisi lainnya yang diharapkan dari program tersebut. Sedangkan jenis program yang lainnya menurut Suharsimi dan Cepi (2004) adalah program pemrosesan, misalnya, program pemberdayaan. Program pemroresan adalah program-program yang kegiatan pokoknya mengubah bahan mentah (input) 
menjadi bahan jadi sebagai hasil proses atau keluaran (output), misalnya dalam program pemberdayaan masyarakat.

PNPM tergolong dalam program pengembangan orang yang bertujuan meningkatkan keberdayaan orang, dan juga tergolong program pemrosesan atau program pemberdayaan yang berfungsi mengubah bahan mentah masyarakat yang tidak mampu menjadi bahan jadi hasil PNPM output atau product sebagai hasil proses pelaksanaan PNPM. Di dalam pelaksanaan program tersebut didasarkan pada context yang antara lain memerlukan analisis kebutuhan masyarakat miskin.

Sedangkan Program Penguatan SIDa juga melakukan pemberdayaan terhadap masyarakat, bahkan termasuk komponen sweasta, akademisi dan birokrasi, yang berfungsi untuk merubah produk atau jasa agar memiliki nilai tambah (added value) sehingga pada akhirnya akan membuat daerah yang bersangkutan memiliki daya saing yang meningkat.

Dengan demikian, model evaluasi program yang cocok (sesuai) digunakan dalam mengevaluasi PNPM dan Program Penguatan SIDa tersebut adalah CIPP Evaluation Model (Context-Input-ProcesProduct) yang dikembangkan oleh Stufflebeam, et al. di Ohio State University.

Selain argumen keeratan jenis program di atas, CIPP Evaluation Model dipakai dengan pertimbangan berikut ini:

1. CIPP Model merupakan sasaran evaluasi yang tidak lain adalah komponen dari proses sebuah program aktivitas, yang berarti bahwa model itu memandang program yang dievaluasi sebagai sebuah sistem, seperti halnya sistem PNPM yang dievaluasi ini dan masuknya program SIDa.

2. Program pemroresan atau pemberdayaan masyarakat (PNPM) mengubah masyarakat miskin (input) menjadi masyarakat yang berkemampuan dalam kehidupannya (output/product), sebagai hasil transformasi (transformation). Konkritnya, isi program dalam PNPM mengubah masyarakat yang kurang mampu (terutama dari aspek ekonomi) menjadi mampu secara ekonomi (product yang diharapkan terjadi), terjadi dalam suatu process (proses transformasi) sampai masyarakat semakin berdaya secara ekonomi. Program tersebut senada dengan program penguatan SIDa yang bertujuan menjadikan masyarakat lebih sejahtera dengan mewujudkan peningkatan ekonomi melalui peningkatan daya saing daerahnya.

3. PNPM harus didasarkan pada analisis masalah yang kemudian menjadi kebutuhan masyarakat, dan di dalam pelaksanaannya berpatokan pada tujuan program yang telah ditentukan sebelumnya. Atau, sesuai dengan context analysis (ruang lingkup program), yaitu konteks di mana program atau material yang ada harus diuji terlebih dahulu secara mendetil untuk dapat mengenali hal-hal yang berpengaruh di dalam pelaksanaan PNPM. Pengenalan ruang lingkup program pada PNPM, ternyata merupakan bagian dari ruang lingkup program Penguatan SIDa yang kemudian diperluas dengan menambah peran swasta, akademisi, dan pemerintah secara lebih aktif. Tujuan program dalam Penguatan SIDa adalah melakukan terobosan inovasi (breakthrough) dengan memberi nilai tambah pada barang ataupun jasa yang dihasilkan oleh daerah. Penguatan SIDa akan melahirkan daya saing daerah yang lebih tinggi.

4. Informasi yang diperlukan dalam penelitian ini adalah informasi atau data yang berkaitan dengan: relevansi kebutuhan masyarakat, kehidupan masyarakat, dan masyarakat yang menjadi sasaran program tersebut yang dilaksanakan, kekuatan komponen input program dalam merealisasikan tujuan program, efektivitas proses pelaksanaan PNPM dalam mencapai tujuan program, dan produktivitas program yang sesuai dengan tujuan program. Komponen input dalam PNPM juga menjadi sebagian dari komponen input untuk Program Penguatan SIDa yang merupakan perluasan program. Kesemua informasi tersebut dapat diperoleh dengan menggunakan model evaluasi CIPP.

5. Dalam praktiknya, CIPP Model "menekankan" pada langkah atau tahapan program dan pada komponen-komponen program (konteks, masukan, proses, dan hasil) yang komprehensif. Atau, objek sasaran evaluasinya pada tahap context, input, process, hingga tahap product merupakan satu rangkaian yang utuh (kendati bisa juga hanya dilakukan satu tahap atau kombinasi dua atau tiga tahap evaluasi tersebut), yang berarti bahwa CIPP Model dengan jelas menunjukkan sebuah sistem atau proses dalam program. Inilah yang menjadi keunggulan (excellence) format evaluasi CIPP Model dibandingkan dengan model evaluasi lainnya. Fokus evaluasi PNPM dan Penguatan SIDa yang dilakukan dalam penelitian ini mengarah pada sasaran evaluasi/penilaian seperti itu (CIPP Model).

6. Oleh karena CIPP Model berorientasi pada keputusan (Stufflebeam dan Shinkfield, 2000), maka model evaluasi ini mempunyai keunikan (uniqueness) tersendiri, yaitu pada tiap tahapan evaluasi terikat pada perangkat pengambilan keputusan yang bertalian dengan perencanaan dan operasi sebuah program yang dievaluasi

Selanjutnya, berdasarkan konsep CIPP Evaluation Model, untuk kepentingan pengambilan keputusan (orientasi formatif), pada tipe evaluasi context merupakan petunjuk untuk pilihan tujuantujuan yang objektif dan tugas yang diprioritaskan. Pada tipe evaluasi input merupakan petunjuk untuk pilihan dari strategi program. Input adalah spesifikasi mengenai disain prosedural. Sedangkan pada tipe evaluasi process merupakan petunjuk untuk 
implementasi. Adapun pada tipe evaluasi product merupakan petunjuk untuk menghentikan, melanjutkan, memodifikasi, atau memprogram ulang sebuah program. Kemudian, relevansi keempat tipe evaluasi tersebut dengan kepentingan akuntabilitas (orientasi sumatif) adalah, pada tipe evaluasi context merupakan rekaman yang objektif dan dasar-dasar pilihan dengan sebuah kebutuhan, peluang, dan berbagai permasalahan. Pada tipe evaluasi input merupakan rekaman tentang pilihan strategi dan disain serta pertimbangan yang dipilih melalui alternatif-alternatif lain. Sedangkan pada tipe evaluasi process merupakan rekaman proses aktual. Adapun pada tipe evaluasi product merupakan rekaman pencapaian dan keputusan ulang (Madaus, Scriven, dan Stufflebeam, 2000). Dengan demikian, setiap tipe evaluasi dalam CIPP Model berbeda relevansinya dengan pengambilan keputusan dan akuntabilitas.

\section{HASIL DAN PEMBAHASAN}

Hasil penelitian evaluasi terhadap PNPM dan Penguatan SIDa berdasarkan model CIPP di 10 (sepuluh) Provinsi wilayah barat Indonesia yaitu 7 (tujuh) provinsi di Sumatera yaitu Provinsi Riau, Provinsi Sumatera Utara, Provinsi Sumatera Selatan, Provinsi Lampung, Provinsi Sumatera Barat, Provinsi Jambi, Provinsi Bengkulu dan 3 (tiga) Provinsi di Jawa yaitu Provinsi Jawa Barat, Provinsi Jawa Tengah, Provinsi DI.Yogyakarta. Dari 10 provinsi tersebut, kemudian dipilih secara acak (random) masing-masing 1 (satu) kabupaten setiap provinsi berarti sejumlah 10 kabupaten, dan selanjutnya dipilih lagi secara random masingmasing 1 (satu) kecamatan dari setiap kabupaten sehingga terpilih 10 kecamatan. Dengan demikian, ada 10 (sepuluh) kecamatan yang menjadi sasaran riset evaluasi PNPM ini. maka diperoleh:

1. Komponen Konteks

a. Untuk tujuan, sasaran dan lingkup pendanaan PNPM-M Tujuan PNPM sudah mengadopsi sesuai yang terkandung dalam Petunjuk Teknis Operasional (PTO), namun untuk implementasinya masih belum maksimal dan perlu pendampingan lebih lanjut, misi yang terkandung dalam PTO untuk pelembagaan sistem pembangunan partisipatif secara merata telah dapat dijalankan secara maksimal, Penentuan kelompok sasaran sudah sesuai dengan tujuan awal yaitu untuk meningkatkan kesejahteraan dan kesempatan kerja masyarakat miskin di perdesaan, Pemilihan dan penentuan lokasi sesuai dengan pendataan yang ada hanya besaran dana yang diterima per desa berbeda-beda tergantung jumlah RTM. mekanisme pembinaan, kebutuhan riil masyarakat miskin di desa akan program, dan fisibilitas (kelayakan), penyelenggara (kelembagaan/ pelaku) PNPM Mandiri adalah adanya analisis kebutuhan riil masyarkat sebelum PNPM-M dilaksanakan, Kesinkronan musrenbangdes dengan musdes menjadi skala prioritas desa, hasil musdes menjadi yang tertuang dalam RKPDes dan akan diajukan sebagai instrumen pengusulan PNPM-M, adanya pertemuan untuk mengevaluasi perkembangan PNPM-M, pengetahuan masyarakat tentang hak-hak yang dimiliki masyarakat, dan kelompok terjadi peningkatan, tetapi belum optimal, System pembangunan partisipasif di desa dapat terlembaga, sedangkan untuk antar desa belum dapat terlembaga secara optimal.

b. Pelembagaan sistem pembangunan partisipatif merupakan cikal bakal dari pelaksanaan program penguatan sistem inovasi daerah, dimana pemberdayaan masyarakat merupakan bagian cluster-cluster inovasi yang memang sudah ada di daerah dan harus dikuatkan serta dijadikan sistem melalui penguatan SIDa. Karena itu penguatan SIDa merupakan langkah tindak lanjut dan pengembangan dari cluster-cluster pemberdayaan masyarakat yang sudah ada dan meningkat menjadi daerah-daerah yang memiliki daya saing yang lebih tinggi dibandingkan lainnya. Nilai tambah yang diperoleh dapat diperoleh dari produk barang maupun jasa.

2. Komponen Input,

a. Pada ketersediaan proses dan sumber pendanaan adalah adanya sumber pendanaan untuk pelatihan bagi para pelaku PNPM-M hanya saja untuk pelatihan bagi kelompok masyarakat masih disesuaikan dengan kebutuhan, keterlibatan PNS dalam PNPM. Secara realitas tugas mereka hanya sebatas urusan adminisrasi keuangan dan belum sampai tahap penguasaan lapangan seperti layaknya fasilitator atau konsultan. Sedangkan untuk pendidikan dan pelatihan ketrampilan dilakukan melalui dana kelembagaan, dana operasional PNPM-M maupun dari alokasi surplus tahunan UPK untuk pelatihan masyarakat dan penguatan kelembagaan sesuai dengan kebutuhan masyarakat untuk peningkatan kapasitas dan keberlanjutan kegiatan.

b. Komponen input dalam Penguatan SIDa merupakan pengembangan dari komponen input PNPM, karena komponen yang diberdayakan dalam Penguatan SIDa bukan hanya masyarakat, tetapi juga memberdayakan swasta, akademisi dan birokrasi. Semua memiliki pembagian tugas dalam kelembagaan SIDa. Kelompok masyarakat yang telah dibentuk PNPM tersebut, dapat ditindaklanjuti dalam Program 
Penguatan SIDa sebagai salah satu lembaga pelaksana SIDa dengan menyesuaikan tema dalam roadmap SIDa yang telah disepakati oleh seluruh lembaga SIDa.

3. Komponen Proses

a. Telah dapat terwujudnya desa partisipasi yang mampu membangkitkan partisipasi masyarakat secara penuh. Mekanisme pengusulan kegiatan sudah menjadi ketentuan 3 usulan/desa dan hasil usulan dikoordinasikan dengan SKPD terkait. Partisipasi masyarakat sangat tinggi dalam PNPM-M. Kesetaraan dan keadilan gender dalam PNPM-M menjadi keunikan dalam program ini karena perempuan turut andil di dalamnya. Pelaksanaan PNPM-M belum sepenuhnya menjalankan sangsi hukum secara tegas. Persiapan pelaksanaan PNPM dimulai dari pengadministrasian dengan mengundang semua elemen yang ada didesa. Keterbukaan juga dilakukan dalam mengadakan bahan dan alat terutama dalam proses pelelangan maupun penentuan toko pemasok bahan. Pelaksanaan evaluasi kegiatan hanya dilakukan di wilayah Sumsel dan Sumbar dikarenakan di wilayah sampel yang lain tidak memiliki sentrawan baik di kabupaten maupun di kecamatan. Pelaksanaan pelaporan hasil kegiatan dilakukan secara berjenjang, dari tingkat kecamatan, kabupaten sampai dengan provinsi. Keterlibatan kelompok masyarakat dalam hal perencanaan, pelaksanaan, pengawasan maupun penilaian sangat baik dan apresiatif meski terkadang masih di dominasi oleh informal leader di desa. Masyarakat siap menerima bantuan dan mengembalikan bantuan sesuai dengan ketentuan. Tingkat kemandirian masyarakat belum optimal. Hasil analisis kebutuhan riil masyarakat menjadi masukan dalam perencanaan. Perkembangan kelembagaankelembagaan PNPM-M semakin baik dan masyarakat memiliki kesiapan dalam mengadministrasikan pembukuan. Biaya operasional pelestarian dilakukan secara swadaya. Sangat baiknya keterlibatan RTM dalam PNPM-M. Pengelolaan pengaduan masalah dalam pelaksanaan PNPM-M dilakukan secara rahasia, berjenjang, proporsional, transparan dan partisipatif , seobjektif mungkin, akuntabilitas, menganut prinsip kemudahan, cepat dan akurat. Setiap pengaduan permasalahan mendapat tanggapan dan penyelesaian dengan cepat, pemantauan pelaksanaan PNPM-M dilakukan secara berjenjang, audit dan pemeriksaan keuangan, kompetensi pelaku-pelaku PNPMM dinilai tinggi dalam PNPM-M. b. Dalam tataran proses program penguatan SIDa sudah banyak menginspirasi daerah untuk melakukan percepatan program. Provinsi Jateng memacu program desa yang telah digalang dalam PNPM untuk dikembangkan menjadi Desa Inovasi. Beberapa kelompok masyarakat di Provinsi Sumsel juga sudah mensinergikan kelompok PNPM menjadi cluster inovasi produk dalam program SIDa. Meskipun belum semua daerah melaksanakan program inovasi secara masif, tetapi mayoritas seluruh Provinsi sudah mencanangkan program inovasi di daerahnya masing-masing. Program SIDa masih bervariasi dalam realisasi di lapangan. Ada yang sudah membentuk Tim Koordinasi Daerah dan ada yang telah menyusun Roadmap SIDa. Bahkan di Provinsi Jateng dan Provinsi Sumatera Selatan sudah melahirkan hasil SIDa, yang berbentuk produk unggulan maupun jasa unggulan sehingga memberi nilai tambah terhadap produk maupun jasa tersebut dan kemudian berdampak kepada peningkatan daya saing daerah.

4. Komponen Produk,

a. Masyarakat sebagai penerima program mengalami peningkatan penghasilan melalui usaha yang menjadi sumber penghidupannya.

b. Komponen produk bagi penguatan SIDa, memang belum banyak dirasakan. Tetapi di beberapa daerah tertentu ada yang sudah bisa dijadikan best practise seperti Provinsi Sumatera Selatan, Provinsi Jawa Tengah, Kota Pekalongan, dan Kabupaten Pelalawan. Produk yang dihasilkan seperti sentra karet, sentra kopi, sentra budidaya ikan, dan lainlain. Sementara jasa yang diberikan sepereti e-government melalui fasilitasi komputerisasi perijinan dan pelayanan publik.

Mengamati perkembangan PNPM selama kurun waktu 5 tahun ( 2009 - 2014) serta Program Penguatan SIDa kurun waktu 2 tahun (2012 - 2014), maka exit strategi dari program ini adalah dengan mengambil kebijakan untuk Phasedown untuk mencapai strategi terakhir yaitu Phaseover dan Phaseout. Mengapa dikatakan demikian karena merujuk dari visi PNPM adalah tercapainya kesejahteraan dan kemandirian masyarakat miskin perdesaan. Disamping itu tujuan penguatan SIDa yaitu meningkatkan kapasitas pemerintahan daerah, daya saing daerah, dan pelaksanaan Materplan Percepatan dan Perluasan Pembangunan Ekonomi Indonesia (MP3EI) 2011-2015 diperlukan penguatan Sistem Inovasi Daerah secara terarah dan berkesinambungan. Dari penjelasan tersebut jelas bahwa PNPM akan menciptakan kemandirian masyarakat secara universal sedangkan Program Penguatan SIDa juga mewujudkan kesejahteraan masyarakat melalui peningkatan ekonomi yang 
dilakukan dengan meningkatkan daya saing daerah. Dan juga dengan pertimbangan-pertimbangan teknis dilapangan yaitu :

1. PNPM dilihat dari partisipasi masyarakat sudah sangat baik, mulai dari perencanaan, pelaksanaan sampai dengan pengawasan. Sedangkan penguatan SIDa dilihat tahapan-tahapan proses dan hasil yang telah diperoleh secara langsung oleh pemerintah daerah maupun masyarakat.

2. Untuk melihat kemandirian masyarakat, seyogyanya dapat dicermati setelah PNPM tidak lagi bergulir di masyarakat, sehingga pengukuran kemandirian masyarakat dapat lebih terimplisit secara kongkrit. Kemandirian masyarakat dalam PNPM merupakan langkah awal melakukan program SIDa yang dapat meningkatkan daya saing daerah dan kesejahteraan masyarakat.

3. PNPM dalam kurun waktu 5 tahun telah berjalan (2009-2014) dan dimungkinkan justru akan melahirkan ketergantungan baru bagi masyarakat terutama dalam aspek ekonomi. Potensi negatif dari ketergantungan masyarakat diarahkan menjadi program posistif yang dapat meningkatkan pendapatan ekonomi bagi masyarakat setempat dengan keunggulan produk yang didukung dari hulu ke hilir oleh semua lembaga pendukung SIDa.

4. Terobosan strategi dimulai dari phasedown, phaseover dan phaseout sebagai langkah kongkrit menghentikan program PNPM. Exit Strategy tersebut langsung diarahkan kepada program penguatan SIDa.

\section{SIMPULAN}

Tujuan exit program adalah untuk memastikan keberlanjutan dampak dan kegiatan setelah program berakhir. Oleh karenanya strategi pengakhiran program merupakan bagian yang penting dari suatu program. Program Nasional Pemberdayaan Masyarakat(PNPM) yang sudah dicanangkan sejak tahun 2007 telah banyak menghasilkan, baik dalam mengentaskan kemiskinan, memberdayakan masyarakat dan khususnya meningkatkan perekonomian masyarakat maupun secara umum peningkatan perekonomian bangsa.

Untuk menjaga keberlanjutan PNPM maka dilakukan exit strategy program yang berkesinambungan dan merupakan langkah tindak lanjut dari PNPM. Program yang menjadi exit strategy PNPM tentunya tidak hanya sekedar rutinitas dan stabilitas program. Dari hasil penelitian evaluasi program, maka disimpulkan bahwa exit strategy program lanjutan tersebut adalah program yang dapat menjaga kesinambungan PNPM serta dapat memberi nilai tambah terhadap masyarakat yang diberdayakan dalam PNPM. Nilai tambah tersebut diperoleh dalam Program Penguatan SIDa yang memberikan pemberdayaan kepada masyarakat dan juga pihak swasta, akademisi serta birokrasi pemerintah itu sendiri, untuk saling bahu membahu mewujudkan Program Penguatan Sistem Inovasi Daerah (SIDa). Nilai tambah tersebut, pada akhirnya akan menjadi peningkatan daya saing daerah dan kemudian secara nasional menjadi daya saing nasional.

\section{Saran}

Dari simpulan penelitian diatas, maka kami sampaikan saran dan rekomendasi yaitu sebagai berikut: Pertama, program SIDa adalah program yang dapat menjaga kesinambungan program karena dapat memberi nilai tambah dengan melakukan inovasi produk barang maupun jasa bagi daerah. Melalui Program SIDa diharapkan daerah akan memiliki daya saing yang lebih tinggi dan secara nasional memberikan peningkatan daya saing nasional untuk bersaing dengan negara-negara lain. Kedua, program SIDa yang secara integral menjadi Sistem Inovasi Nasional, merupakan program yang dapat dijadikan program lanjutan dari Program Nasional Pemberdayaan Masyarakat atau exit strategy PNPM. Tindak lanjut program PNPM tersebut akan membuat bangsa Indonesia menjadi bangsa yang maju secara ekonomi, dengan angka kemiskinan yang semakin kecil serta masyarakatnya yang semakin berdaya guna.

\section{DAFTAR PUSTAKA}

Adi, Isbandi Rukminto. 2001. Pemberdayaan, Pengembangan Masyarakat, dan Intervensi Komunitas. Jakarta: F-UI.

Aiken, Lewis R. 1996. Rating Scales and Checklist : evaluation behavior personality and attitude. New York: John Wiley and Sons, Inc.

Berger, PL dan T. Luckmann. 1982. Realitas Konstruksi Sosial, diterjemahkan oleh Syarwani, dkk. Jakarta Sinar Harapan.

Brinkerhoff, Robert. O, et al. 2003. Program Evaluation. A Source book. Boston: KluwinNydoff Publ.

Chamber, Robert. 1995. "Poverty and Livelihood: Whose Reality Counts", in Discussion Paper 347. Brighton: Institute of Development Studies.

Chambers, Robert and Gordon Conway. 1992. "Sustainable Rural Livelihoods: Practical Concepts for the 21st Century", in Discussion Paper 296. Brighton: Institute of Development Studies.

Cox, David. 2004. "Outline of Presentation on Poverty Alleviation Programs in the Asia-Pacific Region", Makalah yang disampaikan pada International Seminar on Curriculum Development for Social Work Education in Indonesia. Bandung: Sekolah Tinggi Kesejahteraan Sosial, 2 Maret.

Curriculum Development and Evaluation: The CIPP Model. $2007 \quad$ (http://www.scis.nova.edu/terrell/doctoral/1998/dcte747/cipp.html).

Daniel L. Stufflebeam, "Evaluation Models”, Number 89, Spring 2001, Jossey Bass 
Ellis, Frank. 1998. "Household Strategies and Rural Livelihood Diversification", The Journal of Development Studies, Vol.35, No.1, pp.1-38.

Hendra, Roy. 2010. Determinan Kemiskinan. Jakarta: FE UI, 2010.

Hikmat, Harry. 2001. Strategi Pemberdayaan Masyarakat. Bandung: Humaniora Utama Press.

Ife, Jim. 1996. Pembangunan Masyarakat : Analisis dan Praktik, diterjemahkan oleh Taufik Rohman. Jakarta: CFMS.

Kartasasmita, Ginanjar. 1996. Pemberdayaan Masyarakat : Konsep Pembangunan yang Berakar pada Pemerataan. Jakarta: CIDES.

Kaufman, Roger A. dan Susan Thomas. 2002. Evaluation Without Fear. New York: New Viewpoints.

Moeljarto, Vidhyandika. 1996. "Pemberdayaan Kelompok Miskin Melalui Program IDT", dalam Onny S. Prijono dan A.M.V. Pranarka. 1996. Pemberdayaan : Konsep, Kebijakan, dan Implementasi. Jakarta: CIDES.

Moser, Caroline O.N. 1998. "The Asset Vulnerability Framework: Reassessing Urban Poverty Reduction", World Development, Vol.26, No.1, pp.1-19.

Patton, Michael Quinn. 2000. Qualitative Evaluation and Research Methods. Second Edition. Newbury Park, California: Sage Publications.

Peraturan Bersama Menteri Negara Riset dan Teknologi Nomor 03 Tahun 2012 dan Menteri Dalam Negeri Nomor 36 Tahun 2012 tentang Penguatan Sistem Inovasi Daerah.

Piven, Frances Fox Piven dan Richard A. Cloward. 1993. Regulating The Poor: The Functions of Public Welfare. NY: Vintage Books.

Pranarka, A.M.W. 1996. "Globalisasi Pemberdayaan dan Demokratisasi", dalam Onny S. Prijono dan A.M.V. Pranarka. 1996. Pemberdayaan : Konsep, Kebijakan, dan Implementasi. Jakarta: CIDES.

Pranarka, A.M.W. dan Vidhiyandika Morljarto. 1996. "Pemberdayaan (Empowerment)", dalam Onny S. Prijono dan A.M.V. Pranarka. 1996. Pemberdayaan : Konsep, Kebijakan, dan Implementasi. Jakarta: CIDES.

Prihartini, www.resitory.gunadarma.ac.id

Rolf P. Lynton dan Udai Pareek-Pelatihan dan Pengembangan Tenaga Kerja, Pustaka Binaman Jakarta 1998
Sahdan, Gregorius. 2007. Kemiskinan Desa. Yogyakarta: STPMD.

Satterthwaite, David. 1997. "Urban Poverty: Reconsidering its Scale and Nature", IDS Bulletin, Vol.28.

Sugiyono, 2008. Metode Penelitian Bisnis. Cetakan keduabelas, 2008, Penerbit Alfabeta, Bandung.

Suharsimi Arikunto dan Cepi Sfrudin Abdul Jabar, 2004, Evaluasi Program Pendidikan, Jakarta, Bumi Aksara.

Sumodiningrat, Gunawan. 2000. Pemberdayaan Masyarakat dan JPS. Jakarta: PT Gramedia.

Surat Mendagri No. 414.2/316/PMD Perihal PTO PNPM Mandiri Perdesaan Tahun Anggaran 2008.

Swanson, Jean. 2001. Poor-Bashing: The Politics of Exclusion. New York: Mc. Graw-Hill.

Taufik, Tatang A. 2007. "Pengenalan Konsep Sistem Inovasi." Bahan paparan disampaikan pada Workshop Nasional: Strategi Pengelolaan Keuangan Daerah Sebagai Langkah Awal Keberpihakan Pemerintah Daerah terhadap Rakyat Miskin Yogyakarta 11 Mei 2007.

Tjokrowinoto, Moeljarto. 1996. Pembangunan: Dilema dan Tantangan. Yogyakarta: Pustaka Pelajar.

Totok Mardikanto, Poerwoko Soebiato, 2012, Pemberdayaan Masyarakat Dalam Perspektif Kebijakan Publik, Bandung, Alfabeta.

World Agroforestry Center. The CIPP Evaluation Model. $2007 \quad$ (http:/www.konowledge. irri.org/cglrc/icraf/toolkit/The CIPP evaluation model.ht...).

Worthen, B.R and James R. Sanders. 1993. Educational Evaluation L Theory and Practice. Belmont: Wadsworth Publishing Company, Inc. 
Tabel 1. Exit Strategy Pasca Program Nasional Pemberdayaan Masyarakat

\begin{tabular}{|c|c|c|c|c|}
\hline \multirow{2}{*}{ KEGIATAN EXIT } & \multicolumn{2}{|c|}{ AKTOR PELAKU } & \multirow{2}{*}{$\begin{array}{l}\text { MEKANISME } \\
\text { MONITORING }\end{array}$} & \multirow{2}{*}{ BIAYA } \\
\hline & PELAKSANA & PEMANTAU & & \\
\hline \multicolumn{5}{|c|}{$\begin{array}{l}\text { Exit Strategy Fase penurunan (Phasedown) Wilayah Indonesia Bagian Barat } \\
\text { (Thn } 2009 \text {-2014) }\end{array}$} \\
\hline $\begin{array}{l}\text { Pemberian alokasi dana PNPM } \\
\text { yang tidak sama di tahun } \\
\text { berikutnya. Dengan indikator } \\
\text { keberhasilan : } \\
\text { a. Pengurangan Rumah } \\
\text { Tangga Miskin secara } \\
\text { signifikan. } \\
\text { b. Paritisipasi masyarakat baik } \\
\text { dalam hal perencanaan, } \\
\text { pelaksanaan maupun } \\
\text { pengawasan }\end{array}$ & Pemerintah & Pemerintah & $\begin{array}{l}\text { Berdasarkan laporan } \\
\text { tahunan atau laporan } \\
\text { bulanan yang } \\
\text { disampaikan } \\
\text { Kabupaten melalui } \\
\text { Pemerintah Provinsi } \\
\text { kepada Pemerintah } \\
\text { Pusat }\end{array}$ & APBN \\
\hline $\begin{array}{l}\text { Penarikan Program Secara } \\
\text { Bertahap dan menerapkan } \\
\text { Sistem Inovasi Daerah dengan } \\
\text { pertimbangan: } \\
\text { a. Lokasi sasaran yang telah } \\
\text { mencapai titik peningkatan } \\
\text { kapasitas baik kemampuan } \\
\text { masyarakat, perbaikan } \\
\text { ekonomi dan insfrastruktur } \\
\text { b. Pengurangan jumlah RTM } \\
\text { berdasarkan data statistik } \\
\text { c. Melaksanakan kebijakan } \\
\text { penguatan Sistem Inovasi } \\
\text { Daerah } \\
\end{array}$ & $\begin{array}{l}\text { Pemerintah Pusat } \\
\text { dengan dibantu } \\
\text { rekomendasi dari } \\
\text { Provinsi dan } \\
\text { Kabupaten/ Kota }\end{array}$ & $\begin{array}{l}\text { Pemerintah Pusat } \\
\text { dengan dibantu } \\
\text { rekomendasi dari } \\
\text { Provinsi dan } \\
\text { Kabupaten/ Kota }\end{array}$ & $\begin{array}{l}\text { Pendampingan dan } \\
\text { supervisi secara } \\
\text { komprehensif }\end{array}$ & APBN \\
\hline \multicolumn{5}{|c|}{$\begin{array}{l}\text { Exit Strategy Fase Pengalihan (Phaseover) Wilayah Indonesia Bagian Barat } \\
\text { (Thn 2009-2014) }\end{array}$} \\
\hline $\begin{array}{l}\text { Penyerahan kewenangan dari } \\
\text { Pemerintah Pusat kepada } \\
\text { Pemerintah Provinsi dan } \\
\text { Kabupaten/Kota }\end{array}$ & $\begin{array}{l}\text { Pemerintah Pusat, } \\
\text { pemerintah Provinsi } \\
\text { dan Kabupaten/ } \\
\text { Kota }\end{array}$ & $\begin{array}{l}\text { Pemerintah Pusat, } \\
\text { pemerintah Provinsi } \\
\text { dan Kabupaten/ Kota }\end{array}$ & $\begin{array}{l}\text { Berdasarkan } \\
\text { perkembangan } \\
\text { kemajuan PNPM } \\
\text { berdasarkan tahun ke } \\
\text { tahun }\end{array}$ & APBN \\
\hline $\begin{array}{l}\text { Penyerahan pengelolaan dana } \\
\text { PNPM terintegrasi kepada } \\
\text { pemerintah desa tanpa melalui } \\
\text { kecamatan }\end{array}$ & $\begin{array}{l}\text { Pemerintah Pusat, } \\
\text { pemerintah Provinsi } \\
\text { dan Kabupaten/ } \\
\text { Kota termasuk } \\
\text { pemerintah desa }\end{array}$ & $\begin{array}{l}\text { Pemerintah Pusat, } \\
\text { pemerintah Provinsi } \\
\text { dan Kabupaten/ Kota } \\
\text { termasuk pemerintah } \\
\text { desa }\end{array}$ & $\begin{array}{l}\text { Berdasarkan laporan } \\
\text { tahunan dan bulanan } \\
\text { dan tingginya tingkat } \\
\text { pelanggaran yang } \\
\text { dilakukan oleh } \\
\text { pelaku PNPM } \\
\text { khususnya banyak } \\
\text { terjadi di UPK }\end{array}$ & APBN \\
\hline $\begin{array}{l}\text { Melaksankan Penataan Unsur } \\
\text { Sistem Inovasi Daerah yaitu } \\
\text { untuk kelembagaan, jaringan } \\
\text { dan sumber daya SIDa }\end{array}$ & $\begin{array}{l}\text { Pemerintah Pusat, } \\
\text { pemerintah Provinsi } \\
\text { dan Kabupaten/Kota }\end{array}$ & $\begin{array}{l}\text { Pemerintah Pusat, } \\
\text { pemerintah Provinsi } \\
\text { dan Kabupaten/Kota }\end{array}$ & $\begin{array}{l}\text { Berdasarkan } \\
\text { Peraturan Bersama } \\
\text { Mendagri \& } \\
\text { Menristek No } 03 \text { dan } \\
\text { 36 Tahun } 2012 \\
\end{array}$ & APBN \\
\hline \multicolumn{5}{|c|}{$\begin{array}{l}\text { Exit Strategy Fase Penghentian (Phaseout) Wilayah Indonesia Bagian Barat } \\
\text { (Thn } 2009-2014) \text { : Dilakukan pasca program }\end{array}$} \\
\hline $\begin{array}{l}\text { Penguatan UPK Sebagai Basis } \\
\text { Lembaga Perekonomian Desa } \\
\text { melalui : } \\
\text { a. Pembuatan SOP UPK } \\
\text { b. Terbitnya legalitas UPK } \\
\text { (Perbup/Perda) }\end{array}$ & $\begin{array}{l}\text { Pemerintah, } \\
\text { Pemerintah Provinsi/ } \\
\text { Kabupaten }\end{array}$ & $\begin{array}{l}\text { Pemerintah, } \\
\text { Pemerintah Provinsi/ } \\
\text { Kabupaten }\end{array}$ & $\begin{array}{l}\text { Koordinasi elemen } \\
\text { tokoh di Kab/ } \\
\text { kecamatan/ desa }\end{array}$ & $\begin{array}{l}\text { APBN/ } \\
\text { APBD }\end{array}$ \\
\hline
\end{tabular}




\begin{tabular}{|c|c|c|c|c|}
\hline $\begin{array}{ll}\text { c. } & \text { Kualifikasi aktor UPK } \\
\text { secara Profesional }\end{array}$ & & & & \\
\hline $\begin{array}{l}\text { Penarikan fasilitator dari desa } \\
\text { penerima PNPM untuk } \\
\text { diberdayakan dalam program } \\
\text { pemberdayaan lainnya. }\end{array}$ & $\begin{array}{l}\text { Pemerintah, } \\
\text { Pemerintah Provinsi/ } \\
\text { Kabupaten }\end{array}$ & $\begin{array}{l}\text { Pemerintah, } \\
\text { Pemerintah Provinsi/ } \\
\text { Kabupaten }\end{array}$ & $\begin{array}{l}\text { Berdasarkan laporan } \\
\text { kinerja Fasilitator } \\
\text { baik laporan bulanan } \\
\text { ataupun laporan } \\
\text { tahunan }\end{array}$ & APBN \\
\hline $\begin{array}{l}\text { Membuat Laporan Kinerja } \\
\text { PNPM dilihat dari aspek input, } \\
\text { output, outcomes dan benefits }\end{array}$ & $\begin{array}{l}\text { Pemerintah, } \\
\text { Pemerintah Provinsi/ } \\
\text { Kabupaten }\end{array}$ & $\begin{array}{l}\text { Pemerintah, } \\
\text { Pemerintah Provinsi/ } \\
\text { Kabupaten }\end{array}$ & $\begin{array}{l}\text { Berdasarkan laporan } \\
\text { kinerja Fasilitator } \\
\text { baik laporan bulanan } \\
\text { ataupun laporan } \\
\text { tahunan }\end{array}$ & APBN \\
\hline $\begin{array}{l}\text { Melaksanakan pengembangan } \\
\text { SIDa yaitu dengan } \\
\text { pembangunan komitmen dan } \\
\text { konsensus unsur-unsur SIDa } \\
\text { didaerah; Pemetaan potensi dan } \\
\text { analisis SIDa; Pemberlanjutan } \\
\text { penguatan SIDa }\end{array}$ & $\begin{array}{l}\text { Pemerintah, } \\
\text { Pemerintah Provinsi/ } \\
\text { Kabupaten }\end{array}$ & $\begin{array}{l}\text { Pemerintah, } \\
\text { Pemerintah Provinsi/ } \\
\text { Kabupaten }\end{array}$ & $\begin{array}{l}\text { Berdasarkan } \\
\text { Peraturan Bersama } \\
\text { Mendagri \& } \\
\text { Menristek No } 03 \text { dan } \\
36 \text { Tahun } 2012 \text { dan } \\
\text { Roadmap SIDa yang } \\
\text { sudah ditetapkan }\end{array}$ & APBN \\
\hline
\end{tabular}

